\title{
Comparative In Vitro Assessment of the Methanol Extracts of the Leaf, Stem, and Root Barks of Cnidoscolus aconitifolius on Lung and Breast Cancer Cell Lines
}

\section{Cnidoscolus aconitifolius'un Yaprak, Gövde ve Kök Kabuklarının Metanol Ekstrelerinin Akciğer ve Meme Kanseri Hücre Hatlarında Karşılaştırmalı in Vitro Değerlendirilmesi}

\author{
(D) Emmanuel Oise IKPEFAN ${ }^{*}$, (D) Buniyamin Adesina AYINDE², (I) Azhar MUDASSIR 3 , (D) Ahsana Dar FAROOQ 3 \\ 1Delta State University, Faculty of Pharmacy, Department of Pharmacognosy and Traditional Medicine, Abraka, Nigeria \\ 2University of Benin, Faculty of Pharmacy, Department of Pharmacognosy, Benin City, Nigeria \\ 3University of Karachi, International Centre for Chemical and Biological Sciences, Dr. Panjwani Center for Molecular Medicine and Drug Research, Karachi, Pakistan
}

\begin{abstract}
Objectives: Cnidoscolus aconitifolius Mill. I.M.Johnst. is a medicinal plant widely used in ethnomedicine for the treatment of cancer and other diseases.

Materials and Methods: The effects of methanol extracts of the leaf, stem, and root barks were evaluated on breast (MCF-7) and lung (NCI-H460) cancer cells at $1-250 \mu \mathrm{g} / \mathrm{mL}$ using the SRB assay and the extracts were screened for phytochemicals using the standard method.

Results: The stem and root extracts showed no activity at the maximum concentration, while the leaf extract at $100 \mu \mathrm{g} / \mathrm{mL}$ showed remarkable cell growth inhibition against breast $(-14.50 \pm 0.58)$ and lung cancer $(+53.29 \pm 4.57)$ in vitro. The extracts showed the presence of saponins, terpenes, cardiac glycosides, and phenolic compounds. Partitioning of the active leaf extract further enhanced its activity as the chloroform fraction exhibited $\mathrm{GI}_{50}, \mathrm{LC}_{50}$, and total growth inhibition (TGl) of $22.5,68.75$, and $43.75 \mu \mathrm{g} / \mathrm{mL}$ against breast cancer, respectively, and $\mathrm{Gl} \mathrm{I}_{50}$ and TGl of 35.4 and $55.8 \mu \mathrm{g} /$ $\mathrm{mL}$ against lung cancer cells, respectively. However, the aqueous fraction showed no cytotoxicity against either cell line.

Conclusion: These results justified the ethnomedicinal uses of the plant against tumor-related ailments. Isolation of the constituents responsible for the observed activity needs to be carried out to further support this claim.
\end{abstract}

Key words: Cytotoxicity, Cnidoscolus aconitifolius, growth inhibition, MCF-7, NCl-H460, cancer cells

ÖZ

Amaç: Cnidoscolus aconitifolius Mill. I.M.Johnst. kanser ve diğer hastalıkların tedavisinde yaygın olarak kullanılan tıbbi bir bitkidir.

Gereç ve Yöntemler: Yaprak, kök ve kök kabuklarının metanol ekstrelerinin etkileri, SRB yöntemi kullanılarak 1-250 $\mu \mathrm{g} / \mathrm{mL}$ konsantrasyonda meme (MCF-7) ve akciğer ( $\mathrm{NCl}-\mathrm{H} 460)$ kanser hücreleri üzerinde değerlendirilmiş ve ekstrelerin fitokimyasal içeriği standart yöntem kullanılarak taranmıştır.

Bulgular: Gövde ve kök ekstreleri maksimum konsantrasyonda aktivite göstermezken, yaprak ekstresi $100 \mu \mathrm{g} / \mathrm{mL}$ dozda meme $(-14,50 \pm 0,58)$ ve akciğer kanserine $(+53,29 \pm 4,57)$ karşı belirgin in vitro hücre büyümesi inhibisyonu göstermiştir. Ekstrelerde saponinler, terpenler, kardiyak glikozitler ve fenolik bileşiklerin varlığı saptanmıştır. Aktif yaprak ekstresinin fraksiyonlanması ile kloroform fraksiyonunda meme kanseri hücrelerine karşı sırasıyla $22,5,68,75$ ve $43,75 \mu \mathrm{g} / \mathrm{mL} \mathrm{Gl}_{50}, \mathrm{LC}_{50}$ ve toplam büyüme inhibisyonu (TGl) değerleriyle; akciğer kanseri hücrelerine karşı sırasıyla 35,4 ve $55,8 \mu \mathrm{g} / \mathrm{mL} \mathrm{Gl}_{50}$ ve TGI değerleriyle aktivitenin arttığı tespit edilmiştir. Bununla birlikte, sulu fraksiyon her iki hücre hattına karşı sitotoksik etki göstermemiştir.

*Correspondence: E-mail: ikpefanemmanuel@delsu.edu.ng, Phone: +234 8062366928 ORCID: orcid.org/0000-0002-8484-423X

Received:24.04.2018, Accepted: 03.07.2018

๑Turk J Pharm Sci, Published by Galenos Publishing House. 
Sonuç: Bu sonuçlar, bitkinin tümörle ilgili hastalıklara karşı etnomedikal kullanımını desteklemiştir. Bu kaydın desteklenmesi için ileri çalışmalarda aktiviteden sorumlu bileșiklerin izole edilmesi gerekmektedir.

Anahtar kelimeler: Sitotoksisite, Cnidoscolus aitifitifolius, büyüme inhibisyonu, MCF-7, NCl-H460, kanser hücreleri

\section{INTRODUCTION}

Traditionally, medicinal plants have found applications in the formulation and production of modern drugs. They are used in the treatment of severe life-threatening ailments including cancer especially in developing countries.' Over the years, cancer patients have relied on surgery, radiotherapy, and chemical derived drugs for their treatment, which further damage patients' health and increase their suffering. Hence, there is a need to search for and focus on medicinal plants that are used traditionally in treating tumor-related ailments. One such plant, Cnidoscolus aconitifolius (Mill.) I.M.Johnst., has been used as a constituent of herbal preparations for the treatment of cancer patients by Nigerian herbalists.

C. aconitifolius (Euphorbiaceae) originates from southeast Mexico and Guatemala and the southwestern part of Nigeria. ${ }^{2}$ It is locally known as Iyana Ipaja. ${ }^{3}$ In Nigerian traditional health practices, it is also referred to as "Hospital too far" due to its rapid healing properties against certain health conditions. ${ }^{4}$ In ethnomedicine, it has been reported to have a blood boosting effect in both pregnant women and young anemic children, ${ }^{5}$ and as an antidote for alcoholism, insomnia, and scorpion bites. Previously, the cytotoxic and antiproliferative activity of the methanol extracts of $C$. aconitifolius leaves, stem, and root barks against tadpoles of Ranicep ranninus and radicle length of Sorghum bicolor has been reported. ${ }^{6}$ The cytotoxicity of ethanol extract of its leaf against the brine shrimp has also been noted. ${ }^{7}$ However, there is presently no report on the anticancer activity of this plant. Therefore, the present study was aimed at validating the antitumor ethnomedicinal uses of $C$. aconitifolius using human breast and lung cancer cell lines.

\section{MATERIALS AND METHODS}

\section{Chemicals}

Dimethyl sulfoxide (DMSO), fetal bovine serum, gentamicin sulfate, L-glutamine penicillin streptomycin solution, Roswell Park Memorial Institute-1640 medium (RPMI-1640), sulforhodamine B (SRB), trichloroacetic acid (TCA), tris base, trypan blue, and trypsin-EDTA were purchased from Sigma (St. Louis, MO, USA). Acetic acid (Lab Scan, Ireland), amphotericin B (Formepharma, Pakistan), and doxorubicin (ICN, USA) were also obtained.

\section{Consumables}

The cell culture boats, flasks (25 and $75 \mathrm{~cm}^{2}$ ), centrifuge tubes (15 and $50 \mathrm{~mL}$ ), culture plates (96-well, transparent with flat bottom), and serological pipettes (1, 5, and $10 \mathrm{~mL}$ ) were purchased from Falcon BD (USA). The microcentrifuge tubes (2 $\mathrm{mL}$ ) were purchased from Kartel (Italy).

\section{Equipment}

The equipment included an analytical balance, milligram balance, $\mathrm{pH}$ meter (Precisia, Switzerland), centrifuge, $\mathrm{CO}_{2}$ incubator (Kendro Lab Products, Germany), safety cabinet class 2 (Heraeus Germany), microscope: inverted TS-100 (Nikon, Japan), multiwell microplate reader (Stat fax 2100, Awareness Technology, USA), multiwell plate shaker (PMS 1000, Grant Instruments, UK), ultrasonic bath (MXB6, Grant Instruments), and Neubauer's chamber $\left(0.1 \mathrm{~mm}\right.$ and $0.0025 \mathrm{~mm}^{2}, \mathrm{HBG}$, Germany).

\section{Collection and processing of the plant}

The leaves of $C$. aconitifolius (Mill.) I.M.Johnst. were collected in February 2014 at Sabongida-Ora in Edo State, Nigeria, and the identity of the plant was confirmed by Dr. Shasanya Olufemi, a plant taxonomist. It was preserved at the Forest Research Institute of Nigeria, Ibadan, with herbarium specimen number FHI 109574. The plant material was air dried in the laboratory for 5 days at room temperature, followed by oven drying at $40^{\circ} \mathrm{C}$, and subsequently ground to powder form and stored in an air-tight container.

\section{Extraction of plant materials}

About $2.5 \mathrm{~kg}$ of each plant part was exhaustively extracted in methanol (95\%) using a Soxhlet apparatus, and dried using a rotary evaporator maintained at $40^{\circ} \mathrm{C}$.

\section{Preliminary phytochemical screening}

Phytochemical screenings of the extracts (leaves stem and root barks) were carried out using standard methods previously described. ${ }^{8}$

\section{Sulforhodamine- $B$ assay}

The growth inhibitory activities of methanol extract of $C$. aconitifolius and its fractions were tested using human cancer cell lines [breast (MCF-7) and lung cancer ( $\mathrm{NCl}-\mathrm{H} 460){ }^{9}{ }^{9}$

The stock solutions of plant extracts and fractions were prepared as $40 \mathrm{mg} / \mathrm{mL}$ in DMSO. However, doxorubicin (1 $\mathrm{mM}$ ) was prepared in distilled water. On the experimental day, respective dilutions were prepared in RPMI-1640 containing gentamicin $(50 \mu \mathrm{g} / \mathrm{mL})$.

Monolayer trypsinization, cell viability determination, and cell counting from a confluent flask $\left(75 \mathrm{~cm}^{2}\right)$ were carried out. Cells $(10,000$ cells/well/100 $\mu \mathrm{L}$ for MCF-7 and $\mathrm{NCl}-\mathrm{H} 460)$ were seeded for monolayer formation and incubated in a $\mathrm{CO}_{2}$ incubator at $37^{\circ} \mathrm{C}$ for $24 \mathrm{~h}$. Various concentrations of methanol extracts of $C$. aconitifolius $(1,10,50,100,200$, and $250 \mu \mathrm{g} / \mathrm{mL}$ ) and fractions (1, 25, 50, 75, and 100) were added (100 $\mu \mathrm{L} /$ well) in appropriate wells, followed by incubation for $48 \mathrm{~h}$. Appropriate controls and blanks (drug and extract) were also prepared. At the end of $48 \mathrm{~h}$, time zero- 1 ( $\mathrm{T}_{z 1}$ plate) and time zero- 2 ( $\mathrm{T}_{\mathrm{z} 2}$ plate $)$ 
plates were fixed with gentle addition of $50 \% \mathrm{w} / \mathrm{v}$ cold TCA (50 $\mu \mathrm{L} /$ well) before and after the addition of extract and fractions in experimental plates. These were left at room temperature for $30 \mathrm{~min}$, washed (3x), and dried overnight. After $48 \mathrm{~h}$, the experimental plates were also fixed in a similar manner.

The dried fixed plates were stained with $100 \mu \mathrm{L}$ of sulforhodamine solution $(0.4 \% \mathrm{wt} / \mathrm{vol}$ prepared in $1 \%$ acetic acid) for $10 \mathrm{~min}$, followed by washing (5x) with $1 \%$ acetic acid to remove excess stain, and air-dried. Finally, $100 \mu \mathrm{L}$ of tris base solution $(\mathrm{pH}$ $10.2,10 \mathrm{mM}$ ) was added to solubilize protein bound stain and absorbance was recorded at $545 \mathrm{~nm}$ using a microplate reader. All the experiments were conducted in triplicate. The results of the extracts and fractions were presented as $\mathrm{Gl}_{50}, \mathrm{TGI}$, and $\mathrm{LC}_{50}$ $(\mu \mathrm{g} / \mathrm{mL})$ values.

Fractionation of methanol extract of the leaf of $C$. aconitifolius About $25.0 \mathrm{~g}$ of the crude methanol extract was re-dissolved in methanol-water (1:1) and partitioned exhaustively with chloroform (400 $\mathrm{mL} \times 4$ ) volumes in a separating funnel. The chloroform layer (lower) was collected first, followed by the aqueous fraction. This was repeated until a clear lower layer was obtained. The aqueous and the chloroform fractions were concentrated to dryness on a rotary evaporator and their respective yields noted.

\section{RESULTS}

The $2.5 \mathrm{~kg}$ of the powdered leaves, stem, and roots of $C$. aconitifolius yielded $87.65,71.10$, and $68.43 \mathrm{~g}$ of the methanol extracts, corresponding to $3.5 \%, 2.8 \%$, and $2.7 \%$, respectively.

Phytochemical screening of extract of the leaves, stem, and roots of $C$. aconitifolius showed the presence of saponins, tannins, terpenes, and flavonoids in varying intensities. However, alkaloids and anthraquinones were absent (Table 1).

Results of the effect of the methanol extracts on MCF-7 and $\mathrm{NCl}-\mathrm{H} 460$ cell lines

The methanol extract of leaves produced growth inhibitory and cytotoxic effects on MCF-7 to varying extents. At a concentration of $50 \mu \mathrm{g} / \mathrm{mL}$, the extract had $+63.08 \pm 3.63 \%$ growth inhibition, which became more cytotoxic at 200 and 250 $\mu \mathrm{g} / \mathrm{mL}$ as $-14.70 \pm 0.76$, and $-26.25 \pm 2.18 \%$ were recorded. The

Table 1. Results of the phytochemical screening of methanol extracts of the leaves, stem, and roots of $C$. aconitifolius

\begin{tabular}{llll}
\hline Phytochemical groups & Leaves & Stem bark & Root bark \\
\hline Alkaloids & - & - & - \\
\hline Anthraquinones & - & - & - \\
\hline Tannins/phenolic compounds & ++ & + & + \\
\hline Flavonoids & + & - & - \\
\hline Saponins & ++ & + & + \\
\hline Cardiac glycosides & + & + & ++ \\
\hline Terpenes & +++ & + & ++ \\
\hline
\end{tabular}

+++: Appreciable amount, ++: Moderate amount, +: Minute amounts, -: Not detected
$\mathrm{GI}_{50}$ and $\mathrm{TGI}$ were recorded as $26.67 \pm 3.33$ and $95 \mu \mathrm{g} / \mathrm{mL}$ while the $\mathrm{LC}_{50}$ was greater than $250 \mu \mathrm{g} / \mathrm{mL}$ (Table 2). At the maximum concentration of $250 \mu \mathrm{g} / \mathrm{mL}$, stem and root barks extracts of C. aconitifolius showed no significant activities against breast cancer cell lines.

Extract of $C$. aconitifolius at $50-100 \mu \mathrm{g} / \mathrm{mL}$ exhibited cell growth inhibitory effects on the lung cells unlike the breast cancer cells. Significant growth inhibition ranging between $\sim 28 \%$ and $77 \%$ was recorded in a concentration-dependent manner against the human lung cancer cell line ( $\mathrm{NCl}-\mathrm{H} 460)$. $\mathrm{A} \mathrm{Gl}_{50}$ value of $\sim 59.67$ $\mu \mathrm{g} / \mathrm{mL}$ was recorded, while $\mathrm{LC}_{50}$ and TGI were greater than 250 $\mu \mathrm{g} / \mathrm{mL}$ (Table 3).

Effects of the aqueous and chloroform fractions of $C$. aconitifolius against breast (MCF-7) and lung cancer (NCl-H460) cell lines The chloroform fraction at $25 \mu \mathrm{g} / \mathrm{mL}$ displayed significant growth inhibition of $\sim 48.62 \%$ against MCF-7 cells, which became cytotoxic at $50-100 \mu \mathrm{g} / \mathrm{mL}$ in a concentrationdependent manner with $\mathrm{GI}_{50}, \mathrm{LC}_{50}$, and TGI of 22.50, 68.75, and $43.75 \mu \mathrm{g} / \mathrm{mL}$, respectively (Table 4 ).

Similar effects were also observed with the chloroform fraction against $\mathrm{NCl}-\mathrm{H} 460$ cells, giving $\mathrm{Gl}_{50}$ and $\mathrm{TGl}$ of 35.40 and 55.8

Table 2. Cytotoxicity of methanol extract of $C$. aconitifolius against breast cancer cell line (MCF-7)

\begin{tabular}{|c|c|c|c|c|c|}
\hline \multirow[t]{2}{*}{ Extract } & \multirow[t]{2}{*}{$(\mu \mathrm{g} / \mathrm{mL})$} & \multirow{2}{*}{$\begin{array}{l}\text { \% Growth } \\
\text { inhibition/ } \\
\text { cytotoxicity }\end{array}$} & $\mathrm{GI}_{50}$ & $\mathrm{LC}_{50}$ & TGI \\
\hline & & & \multicolumn{3}{|c|}{$(\mu \mathrm{g} / \mathrm{mL})$} \\
\hline & 1 & $+18.04 \pm 0.61$ & $+26.67 \pm 3.33$ & $>250$ & $95 \pm 0$ \\
\hline & 10 & $+42.38 \pm 2.99$ & & & \\
\hline & 50 & $+63.08 \pm 3.63$ & & & \\
\hline & 100 & $-4.07 \pm 0.58$ & & & \\
\hline & 200 & $-14.70 \pm 0.76$ & & & \\
\hline & 250 & $-26.25 \pm 2.18$ & & & \\
\hline
\end{tabular}

Control absorbance in MCF-7 at $545 \mathrm{~nm}=1.9 \pm 0.1$

Each value represents \% mean \pm standard error of mean of three independent experiments as compared to control. Growth inhibition=+ and cytotoxicity=-; $\mathrm{Gl}_{50}$ and $\mathrm{TGI}=$ Concentration of drug causing $50 \%$ and $100 \%$ growth inhibition of cells. $\mathrm{LC}_{50}=$ Lethal concentration of drug that killed $50 \%$ cells. The order of activity was significantly different from each other.

TGI: Total growth inhibition

Table 3. Cytotoxicity of methanol extract of $C$. aconitifolius against lung cancer cell-line ( $\mathrm{NCl}-\mathrm{H} 460)$

\begin{tabular}{|c|c|c|c|c|c|}
\hline \multirow{2}{*}{$\begin{array}{l}\text { Methanol } \\
\text { extract }\end{array}$} & \multirow{2}{*}{$\begin{array}{l}\text { Conc. } \\
(\mu \mathrm{g} / \mathrm{mL})\end{array}$} & \multirow{2}{*}{$\begin{array}{l}\% \text { Growth } \\
\text { inhibition/ } \\
\text { cytotoxicity }\end{array}$} & $\mathrm{Gl}_{50}$ & $\mathrm{LC}_{50}$ & TGI \\
\hline & & & \multicolumn{3}{|c|}{$(\mu \mathrm{g} / \mathrm{mL})$} \\
\hline & 1 & $0.00 \pm 0.00$ & $+59.67 \pm 0.75$ & $>250$ & $>250$ \\
\hline & 10 & $+28.45 \pm 4.26$ & & & \\
\hline & 50 & $+46.24 \pm 3.24$ & & & \\
\hline & 100 & $+53.29 \pm 4.57$ & & & \\
\hline & 200 & $+64.73 \pm 2.79$ & & & \\
\hline & 250 & $+77.68 \pm 1.96$ & & & \\
\hline
\end{tabular}

Control absorbance in $\mathrm{NCl}-\mathrm{H} 460$ at $545 \mathrm{~nm}=2.0 \pm 0.1$

Each value represents \% mean \pm standard error of mean of three independent experiments as compared to control. Growth inhibition=+ and cytotoxicity=-; $\mathrm{Gl}_{50}$ and $\mathrm{TGl}=$ Concentration of drug causing $50 \%$ and $100 \%$ growth inhibition of cells. $\mathrm{LC}_{50}=$ Lethal concentration of drug that killed $50 \%$ cells. The order of activity was significantly different from each other.

TGl: Total growth inhibition 
$\mu \mathrm{g} / \mathrm{mL}$ with $\mathrm{LC}_{50}>100 \mu \mathrm{g} / \mathrm{mL}$. The aqueous fraction did not show any activity at $100 \mu \mathrm{g} / \mathrm{mL}$ on either cell line (Table 5).

Table 4. Cytotoxicity of the aqueous and chloroform fractions of $C$ aconitifolius against breast cancer (MCF-7) cell line

\begin{tabular}{|c|c|c|c|c|c|}
\hline \multirow{2}{*}{$\begin{array}{l}\text { Chloroform } \\
\text { fraction }\end{array}$} & \multirow{2}{*}{$\begin{array}{l}\text { Conc. } \\
(\mu \mathrm{g} / \mathrm{mL})\end{array}$} & \multirow{2}{*}{$\begin{array}{l}\% \text { Growth } \\
\text { inhibition/ } \\
\text { cytotoxicity }\end{array}$} & $\mathrm{Gl}_{50}$ & $\mathrm{LC}_{50}$ & TGI \\
\hline & & & \multicolumn{3}{|c|}{$(\mu \mathrm{g} / \mathrm{mL})$} \\
\hline & 1 & $+8.32 \pm 1.60$ & 22.50 & 68.75 & 43.75 \\
\hline & 25 & $+48.62 \pm 5.30$ & & & \\
\hline & 50 & $-16.10 \pm 2.30$ & & & \\
\hline & 75 & $-58.30 \pm 6.70$ & & & \\
\hline & 100 & $-72.00 \pm 9.10$ & & & \\
\hline $\begin{array}{l}\text { Aqueous } \\
\text { fraction }\end{array}$ & 100 & $<50$ & $>100$ & $>100$ & $>100$ \\
\hline
\end{tabular}

Each value represents \% mean \pm standard error of mean of three independent experiments as compared to control. Growth inhibition=+ and cytotoxicity=-; $\mathrm{GI}_{50}$ and $\mathrm{TGI}=$ Concentration of drug causing $50 \%$ and $100 \%$ growth inhibition of cells. $\mathrm{LC}_{50}=$ Lethal concentration of drug that killed $50 \%$ cells. The order of activity was significantly different from each other.

TGI: Total growth inhibition

Table 5. Cytotoxicity of the aqueous and chloroform fractions of $C$. aconitifolius against lung cancer ( $\mathrm{NCl}-\mathrm{H} 460)$ cell line

\begin{tabular}{|c|c|c|c|c|c|}
\hline \multirow{2}{*}{$\begin{array}{l}\text { Chloroform } \\
\text { fraction }\end{array}$} & \multirow{2}{*}{$\begin{array}{l}\text { Conc. } \\
(\mu \mathrm{g} / \mathrm{mL})\end{array}$} & \multirow{2}{*}{$\begin{array}{l}\text { \% Growth } \\
\text { inhibition/ } \\
\text { cytotoxicity }\end{array}$} & $\mathrm{GI}_{50}$ & $\mathrm{LC}_{50}$ & TGI \\
\hline & & & \multicolumn{3}{|c|}{$(\mu \mathrm{g} / \mathrm{mL})$} \\
\hline & 1 & $+3.00 \pm 0.72$ & 35.40 & $>100$ & 55.8 \\
\hline & 25 & $+21.00 \pm 2.10$ & & & \\
\hline & 50 & $-2.00 \pm 1.30$ & & & \\
\hline & 75 & $-9.60 \pm 1.20$ & & & \\
\hline & 100 & $-22.00 \pm 11.00$ & & & \\
\hline $\begin{array}{l}\text { Aqueous } \\
\text { fraction }\end{array}$ & 100 & $<50$ & $>100$ & $>100$ & $>100$ \\
\hline
\end{tabular}

Control absorbance in $\mathrm{NCl}-\mathrm{H} 460$ at $545 \mathrm{~nm}=2.0 \pm 0.1$

Each value represents \% mean \pm standard error of mean of three independent experiments as compared to control. Growth inhibition=+ and cytotoxicity=-; $\mathrm{GI}_{50}$ and $\mathrm{TGI}=$ Concentration of drug causing $50 \%$ and $100 \%$ growth inhibition of cells. $\mathrm{LC}_{50}=$ Lethal concentration of drug that killed $50 \%$ cells. The order of activity was significantly different from each other.

TGI: Total growth inhibition

\section{DISCUSSION}

Among all human diseases, cancer remains the most deadly and life-threatening pathological condition. ${ }^{10}$ The global burden of this disease has continued to surge due to the adoption of high level of cancer-inducing lifestyles such as smoking, eating of a westernized diet, and physical inactivity."

According to global cancer statistics, breast and lung cancers are the most frequently diagnosed cancers in females and males, respectively. ${ }^{12}$ The commonly employed treatment includes chemotherapy, radiotherapy, and in some cases surgery, which also exhibit series of side effects among patients. ${ }^{13}$ Due to this, research into ethnomedicinal plants with antitumor properties as an alternative medicine at the early stage of the disease has become necessary.

Phytochemical screening of extracts revealed the presence of various phytochemicals including tannins and flavonoids, which are known to possess free radical scavenging activity, hence preventing the development of diseases. The higher activity demonstrated by the leaf extract over the stem and root extracts could be due to the abundance of one or more secondary metabolites such as terpenes and phenolic compounds, which are known for their antifree radical potentials and inhibition of carcinogenesis. ${ }^{14,15}$

Our previous work demonstrated that the extracts from the leaf, stem, and root barks of $C$. aconitifolius displayed cytotoxic and antiproliferative effects on guinea corn radicle length and tadpoles in vitro. The present study further validates the previous results with the leaf extract being most active against breast and lung cancer cells. This could happen due to variation in the chemical constituents of the different morphological parts of the plant occasioned by translocation.

The leaf extract exhibited a concentration-dependent effect with higher growth inhibitory effect against breast cancer by $\sim 2 x$ than that of lung cancer cells. Partitioning of the extract was observed to increase the activity compared to the crude as the chloroform fraction at $100 \mu \mathrm{g} / \mathrm{mL}$ produces cytotoxicities of $-72 \pm 9.1 \%$ and $-22 \pm 11 \%$ as well as $\mathrm{Gl}_{50}$ of 22.5 and $35 \mu \mathrm{g} / \mathrm{mL}$ against MCF-7 and $\mathrm{NCl}-\mathrm{H} 460$ cells, respectively. This variation in sensitivities of the crude extracts and fraction could be as a result of the interference of some molecular process at some stages in the cell division processes, e.g., the G2/M phase and the induction of some apoptotic process such as mitochondrial transmembrane depolarization. ${ }^{14}$

The results obtained have validated the traditional uses of this plant in the treatment of cancer. However, further work towards the isolation of the constituents responsible for the observed activities is required.

\section{ACKNOWLEDGEMENTS}

The authors are thankful to NAM S\&T center for providing a sixmonth grant to conduct this research as well as the director of the International Center for Chemical and Biological Sciences (ICCBS), University of Karachi, Pakistan, Prof. Muhammad lqbal Choudhary, for providing the necessary facilities to carry out this work.

Conflicts of interest: No conflict of interest was declared by the authors.

\section{REFERENCES}

1. Kolawole AO. Feasible cancer control strategies for Nigeria mini review. Am J Trop Med Pub Health. 2011;1:1-10.

2. Ross-lbarra J, Molina-Cruz A. The Ethnobotany of Chaya (Cnidoscolus aconitifolius ssp. Aconitifolius Breckon): A Nutritious Maya Vegetable. Econ Bot. 2002;56:350-65.

3. Oyagbemi AA, Odetola AA, Azeez O. Ameliorative effects of Cnidoscolus aconitifolius on anaemia and osmotic fragility induced by protein energy malnutrition. J Biotech. 2008;7:1721-6.

4. Donkoh A, Kese AG, Atuahene CC. Chemical composition of chaya leaf meal (Cnidoscolus aconitifolius (Mill.) Johnston) and availability of its amino acids to chicks. Anim Feed Sci Technol. 1990;30:155-62. 
5. Iwalewa EO, Adewunmi CO, Omisore NO Adebanji OA. Pro-anti oxidant effect of vegetables in south west Nigeria. J Med Food. 2005;8:531-4.

6. Ikpefan EO, Ayinde BA, Gita TD. In vitro comparative cytotoxic and growth inhibitory effects of the methanol extracts of the leaf, stem and root barks of Cnidoscolus acontifolius (Mill.) Johnst (Euphorbiaceae). Int J Bioassays. 2013;2:445-9.

7. Senjobi CT, Moody JO, Ettu AO. Antimicrobial and cytotoxic effects of Cnidoscolus aconitifolius. J Agric Biol Sci. 2011;2:21-5.

8. Khandelwal KR. Practical Pharmacognosy, Techniques and Experiments. $15^{\text {th }}$ ed. New Delhi; Nirali Prakashan; 2006:15-163.

9. Skehan P, Storeng R, Scudiero D, Monks A, McMahon J, Vistica D, et al. New colorimetric cytotoxicity assay for anticancer-drug screening. J Natl Cancer Inst. 1990;82:1107-12.

10. Izevbigie EB, Bryant JL, Walker A. A novel natural inhibitor of extracellular signal-regulated kinases and human breast cancer cell growth. Exp Biol Med (Maywood). 2004;229:163-9.
11. Jemal A, Bray F, Center MM, Ferlay J, Ward E, Forman D. Global cancer statistics. CA Cancer J Clin. 2011;61:69-90.

12. Ferlay J, Soerjomataram I, Dikshit R, Eser S, Mathers C, Rebelo M, et al. Cancer incidence and mortality worldwide: sources, methods and major patterns in GLOBOCAN 2012. Int J Cancer. 2015;136:E359-86.

13. Ayinde BA, Ofeimun JO, Kashif M. Kashif M, Farooq AD, Choudhary MI. Growth Inhibitory Evaluations of Four Nigerian Medicinal Plants Against Cancer Cells, with Active Cytotoxic Fractions from the Leaves of Parquetina nigrescens. Can J Pur Appl Sci. 2014;9:3241-5.

14. Miliauskas G, Venskutonis PR, van Beek TA. Screening of radical scavenging activity of some medicinal and aromatic plant extracts. Food Chem. 2004;85:231-7.

15. Zheng W, Wang SY. Antioxidant activity and phenolic compounds in selected herbs. J Agric Food Chem. 2001;49:5165-70. 